\title{
PERAN KEPALA DESA DALAM PEMBANGUNAN DESA DI KECAMATAN MEKARSARI KABUPATEN BARITO KUALA
}

\author{
Bakhtiar \\ Email: bakhtiar8967@gmail.com \\ Rizalul Gadi \\ STIA Bina Banua Banjarmasin
}

\begin{abstract}
The results of the study show that 1) The role of the Village Head in the development of the Village in Mekarsari Subdistrict as a policeman, innovator and stabilizer by carrying out various plans, proposals and actions in achieving a better village development goal. 2) Obstacles of the Village Head in carrying out village development in Mekarsar District, Barito Regency, among others: a) The still low quality of Human Resources or education of officials and the community who carry out the Village development process in Mekarsari District. b) Limited budget for village development in Mekarsari District. c) Low allowances for the Village Head so that the level of welfare of the village head is very low. d) Lack of supervision and guidance to the Village Head from the Regional Government. 3) Solution of the Village Head in implementing Village development in Mekarsar District, Barito Kuala Regency, among others: a) Improving the quality of Human Resources and education of officials and the community who carry out the Village development process in Mekarsari District. b) Propose additional budgets for village development in Mekarsari District. c) Increasing benefits for the Village Head so that the level of welfare of the village head becomes better. d) Improve supervision and guidance to the Village Head from the Regional Government, so that the implementation of development runs smoothly.
\end{abstract}

Keywords: Village Head, Development.

\section{PENDAHULUAN}

Dalam rangka mewujudkan tujuan pembangunan nasional, pemerintah memberikan perhatian yang sebesar-besarnya pada pembangunan di pedesaan.Perhatian yang besar terhadap pedesaan itu didasarkan pada kenyataan bahwa desa merupakan tempat berdiamnya sebagian besar rakyat Indonesia.Kedudukan desa dan masyarakat desa merupakan dasar landasan kehidupan bangsa dan Negara Indonesia.

Desa sebagai kesatuan masyarakat hukum terkecil yang memiliki batas-batas wilayah yang berwenang untuk mengatur dan mengurus kepentingan masyarakatnya berdasarkan asal-usul dan adat-istiadat setempat yang diakui dan dihormati oleh 
negara.Pembangunan pedesaan selayaknya mengarah pada peningkatan kesejahteraan masyarakat pedesaan.Pemberdayaan masyarakat pedesaan dapat dilihat pula sebagai upaya mempercepat pembangunan pedesaan melalui penyediaan sarana dan prasarana untuk memberdayakan masyarakat dan upaya mempercepat pembangunan ekonomi daerah yang efektif dan kokoh.Pembangunan pedesaan bersifat multiaspek, oleh karena itu perlu keterkaitan dengan bidang sektor dan aspek di luar pedesaan sehingga dapat menjadi pondasi yang kokoh bagi pembangunan nasional.

Untuk mewujudkan pemberdayaan, kesejahteraan, dan kemandirian masyarakat perlu didukung oleh pengelolaan pembangunan yang partisipatif. Pada tatanan pemerintahan diperlukan perilaku pemerintahan yang jujur, terbuka, bertanggung jawab dan demokrasi, sedangkan pada tatanan masyarakat perlu dikembangkan mekanisme yang memberikan peluang peran serta masyarakat dalam proses pengambilan keputusan bagi kepentingan bersama.

Penyusunan perumusan strategik merupakan salah satu upaya untuk meningkatkan pembangunan melalui beberapa kegiatan antara lain peningkatan prakarsa dan swadaya masyarakat, perbaikan lingkungan dan perumahan, pengembangan usaha ekonomi desa, pengembangan lembaga keuangan desa serta kegiatan-kegiatan yang dapat meningkatkan kemampuan masyarakat dalam menaikkan hasil produksinya.

Upaya-upaya pemberdayaan masyarakat seharusnya mampu berperan meningkatkan kualitas sumber daya manusia (SDM) terutama dalam membentuk dan merubah perilaku masyarakat untuk mencapai taraf hidup yang lebih berkualitas. Pembentukan dan perubahan perilaku tersebut, baik dalam dimensi sektoral yakni dalam seluruh aspek atau sektor-sektor kehidupan manusia, dimensi kemasyarakatan yang meliputi jangkauan kesejahteraan dari materiil hingga non materiil; dimensi waktu dan kualitas yakni jangka pendek hingga jangka panjang dan peningkatan kemampuan dan kualitas untuk pelayanannya, serta dimensi sasaran yakni dapat menjangkau dari seluruh strata masyarakat. Pemberdayaan masyarakat tidak lain adalah memberikan motivasi dan dorongan kepada masyarakat agar mampu menggali potensi dirinya dan berani bertindak memperbaiki kualitas hidupnya, melalui cara antara lain dengan pendidikan untuk penyadaran dan pemampuan diri mereka. 
Pemberdayaan masyarakat merupakan sebuah strategi yang dilakukan untuk melakukan kemandirian sosial ekonomi masyarakat dalam jangka panjang.Sebagaimana yang terjadi di Kecamatan Mekarsari Kabupaten Barito kuala, pemberdayaan masyarakat lebih difokuskan pada pemberdayaan secara ekonomi sosial, budaya dan politik.

Kecamatan Mekarsari perlu merumuskan sebuah strategi dalam meningkatkan pembangunan Desa dengan berbagai perencanaan yang mantab, sesuai dengan visi kecamatan Mekarsari yaitu mewujudkan masyarakat yang sejahtera berbasis pertanian melalui peningkatan koordinasi dan pelayanan. Sedangkan strategi yang akan dilaksanakan kecamatan Mekarsari adalah peningkatan pelayanan administratif, peningkatan kapasitas aparator pemerintah Desa, pengembangan infrastruktur perdesaan, peningkatan sarana dan keseteraan gender dalam pembangunan dan peningkatan swadaya masyarakat dengan harapan perumusan ini dapat meningkatkan pembangunan yang ada.

Namun tentunya dalam menjalankan perumusan tersebut tidak terlepas dengan adanya berbagai kendala yang ditemukan seperti kurangnya komunikasi dan koordinasi antar aparat terkait dalam melaksanakan perumusan strategik ini, kurangnya pembinaan yang diberikan kepada kepala Desa yang ada di Kecamatan Mekarsari oleh Pemerintah daerah, kurangnya anggaran dana yang dialokasikan untuk pembangunan Desa dan usulan pembangunan yang sangat sedikit.

Secara umum penelitian yang dilakukan untuk menemukan dan mengembangkan serta mengkaji kebenaran dari suatu ilmu pengetahuan, secara khusus penelitian ini bertujuan :

1. Untuk mengetahui dan mengevaluasi peran Kepala Desa dalam pembangunan Desa di Kecamatan Merkarsari Kabupaten Barito Kuala.

2. Untuk mengetahui kendala yang dihadapi Kepala Desa pembangunan Desa di Kecamatan Merkarsari Kabupaten Barito Kuala.

3. Untuk menemukan solusi dalam yang dilakukan dalam mengatasi kendala Kepala Desa dalam pembangunan Desa di Kecamatan Merkarsari Kabupaten Barito Kuala.

\section{TINJAUAN PUSTAKA}

\section{A. Pengertian Peran}


Pada hakekatnya peran yang harus dimainkan oleh seorang administrator birokrasi public, agar kinerja pegawai dapat lebih meningkat. Menurut Ambar Teguh Sulistiyani (2004:93-94) adalah :

1. Peran mempengaruhi

Seorang administrator harus dapat memberikan pengaruhnya kepada staf atau masyarakat yang dilayaninya, sehingga staf atau masyarakat yang dilayaninya mau bekerjasama dalam merealisasikan suatu program kegiatan, dan ini sebenarnya mudah bagi administrator birokrasi public karena kewenangan atasan sangat tinggi. Tetapi kalau hanya mengandalkan kewenangan semata-mata, juga tidak akan memberikan efek yang berarti terhadap straf atau masyarakat yang dilayani. Administrator dapat memodifikasi kewenangan dan keunggulan-keunggulan sefat yang dimiliki oleh seorang administrator.

Ada beberapa hal yang perlu diperhatikan agar peran mempengaruhi staf atau masyarakat yang dilayani lebih efektif :

a. Menjadilah seorang administrator yang jujur, adil terhadap semua staf atau masyarakat yang dilayani tanpa pilih kasih

b. Berusaha memberikan contoh dalam bekerja dan bertindak

c. Bersikap arif dan bijaksana terhadap staf atau masyarakat yang dilayani yang melakukan pelanggaran

d. Senantiasa melibatkan staf atau masyarakat yang dilayani dalam berbagai kegiatan

e. Tumbuhan rasa percaya diri pada staf atau masyarakat yang dilayani, bahwa mereka memiliki kemampuan dan potensi kerja yang tinggi

f. Usahakan staf atau masyarakat yang dilayani tetap merasa dihargai, dengan menjadikan mereka sebagai partner atau tim kerja

g. Pada point satu dan dua administrator disarankan untuk memiliki keteladanan terhadap staf atau masyarakat yang dilayani

Administrator hendaknya memiliki perilaku yang patut menjadi contoh disamping itu administrator hendaknya dapat memberikan keteladanan secara teknis, misalnya dalam bekerja, mampu memberikan konsultasi, pengarahan dan pembinaan. Pada point tiga administrator perlu mengambil tindakan atas prestasi maupun pelanggaran yang terjadi, artinya perlu memberlakukan secara adil reward 
maupun punish kepada staf atau masyarakat yang dilayani. Dalam konteks MSDM kedua konsekuensi ini sangat penting. Pemberian penghargaan kepada pegawai yang berprestasi atau memiliki kinerja yang baik akan menjadi motivator, sedangkan pemberian hukuman kepada pegawai yang melakukan penyimpanan dan pelanggaran secara fungsional akan menjadi alat pengendali. Keadilan merupakan bagian dari nilai-nilai yang dikembangkan oleh Food Governance.Dalam system MSDM seorang administrator hendaknya mampu bertindak adil atas para staf atau masyarakat yang dilayani. Pemberlakuan sestem penghargaann yang proporsional sangat penting dalam membangun "image" akan buah akan perlakuan yang "adil". Adil dalam hal ini adalah adanya porsi perhatian pelayanan seimbang dan selaras terhadap prestasi maupun pelanggaran dan sikap yang kontraproduktif.

Tanpa administrator harus setiap saat memompa semangat untuk bekerja yang baik atau sebaliknya melarang untuk tindakan indisipliner dll, para pegawai telah dapat menempatkan diri dan bersikap dengan baik. Pada point empat administrator perlu menempatkan SDM sebagai bagian penting yang mampu menjadi motor penggerak aktivitas organisasi. Untuk memberikan ruang gerak yang lebih leluasa keadministratoran partisipatif akan membuka ruang bagi anak buah untuk ikut serta memberikan sumbangan pemikiran. Hal ini diperkuat dengan point lima yang memberikan diskresi dalam pengambilan keputusan sesuai dengan bidang masing-masing. Pada point berikutnya staf atau masyarakat yang dilayani tidak semata-mata dipandang undergrade dan inferior melainkan sebaiknya dipandang sebagai partner dalam bekerja. Dengan menerapkan hal-hal tersebut diatas, seorang administrator birokrasi public dapat menjalankan peran mempengaruhi secara lebih efektif.

2. Peran Memotivasi

Pada dasarnya antara peran mempengaruhi dan memotivasi merupakan peran yang sulit dibedakan.Namun peran mempengaruhi adalah bagaimana menanamkan pengaruh seorang administrator agar bawahnya mau mengikutinya.Sementara memotivasi adalah berkaitan dengan pemberian dorongan kepada staf atau masyarakat yang dilayani untuk bekerja lebih giat. Hubungannya antara kedua peran adalah kalau peran mempengaruhi tersebut efektif, maka peran memotivasi akan lebih mudah dilakukan. Sebaliknya jika administrator tidak 
mampu menanamkan pengaruh terhadap bawahannya, maka baginya untuk melakukan motivasi.

Selain kedua peran stratijik diatas, peran stratejik administrator dalam birokrasi public lainnya, kita dapat meminjamkan taksonomi peran manajerial yang dikembangkan Mitzberg (1973), yaitu (1) tiga peran berhubungan dengan lperilaku antar pribadi dari para manajer (administrator, penghubung, administrator yang proforma (figure head), (2) tiga peran berhubungan dengan perilaku pemrosesan informasi (monitor, disseminator, dan juru bicara), dan (3) empat peran berhubungan dengan perilaku pengambilan keputusan (kewirausahawan, menangani konflik, mengalokasikan sumber daya, dan perundingan, (Yulk, 2004).

3. Peran Antar Pribadi

Peran administrator pada peran antar pribadi dalam kaitannya dengan kedudukannya sebagai administrator dalam suatu organisasi, adalah sebagai figure atau kokoh yang cukup dihargai.Administrator harus menampilkan perilaku yang baik dan benar, seperti etos kerja yang tinggi, disiplin, dan sikap positif lainnya.Atau dalam keadministratoran nasional kita dikenal dengan "ingmadya mangun karso, ingarso suntulodo, tut wuri handayani”.Bahwa administrator harus menempatkan diri sebagai penuntun, pemberdaya, dan pendorong bagi staf atau masyarakat yang dilayaninya.

\section{Peran Informasional}

Sementara, peran informasional yang dimiliki oleh seorang administrator sangat strategis, mengingat dia adalah pemegang kunci, khususnya informasi tentang organisasi yang dipimpinnya.Kemampuan komunikasi sangatlah diperlukan oleh seorang administrator agar dapat menjadi komunikator yang efektif. Peran informasional adalah menjelaskan kepada staf atau masyarakat yang dilayani menyangkut rencana-rencana, kebijakan-kebijakan, serta harapan peran, dan instruksi tentang cara pekerjaan harus dilakukan, tanggungjawab kerja bagi para staf atau masyarakat yang dilayani atau anggota, tim, dan tujuan-tujuan kinerja dan otorisasi rencana tindakan untuk mencapainya. Dengan demikian peran informasional yang dilakukan oleh administrator ini adalah mengkomunikasikan suatu informasi oleh seorang manajer yang releban dengan tugas yang dibutuhkan oleh para staf atau masyarakat yang dilayani, serta menyangkut rencana-rencana, 
kebijakan-kebijakan serta harapan peran, dan instruksi tentang cara pekerjaan harus dilakukan, tanggungjawab kerja bagi para staf atau masyarakat yang dilayani atau anggota tim, dan tujuan-tujuan kinerja dan otorisasi rencana tindakan untuk mencapainya.Tujuan pertama dari peran informasional adalah untuk memudahkan pekerjaan dari orang lain tergantung kepada manajer sebagai suatu sumber informasi yang penting. Disamping itu, para pegawai yang selalu diberi informasi mengenai perkembangan-perkembangan penting dalam organisasi kemungkinan akan mempunyai kepuasan kerja yang lebih tinggi.

\section{B. Pemerintahan Desa dan Kepala Desa}

Keberadaan desa telah dikenal lama dalam tatanan pemerintahan di Indonesia bahkan jauh sebelum Indonesia merdeka.Masyarakat di Indonesia secara tradisional dan turun temurun hidup dalam suatu kelompok masyarakat yang disebut dengan desa.Dalam perkembangannya desa kemudian tetap dikenal dalam tata pemerintahan di Indonesia sebagai tingkat pemerintahan yang paling bawah dan merupakan ujung tombak pemerintahan dan diatur dalam peraturan perundang-undangan.

Desa menurut definisi universal, adalah sebuah aglomerasi permukiman di area perdesaan (rural). Di Indonesia, istilah desa adalah pembagian wilayah administratif di Indonesia di bawah kecamatan, yang dipimpin oleh Kepala Desa. Menurut UndangUndang Nomor 06 Tahun 2014 tentang Desa, disebutkan bahwa Desa adalah desa dan desa adat atau yang disebut dengan nama lain, selanjutnya disebut Desa, adalah kesatuan masyarakat hukum yang memiliki batas wilayah yang berwenang untuk mengatur dan mengurus urusan pemerintahan, kepentingan masyarakat setempat berdasarkan prakarsa masyarakat, hak asal usul, dan/atau hak tradisional yang diakui dan dihormati dalam sistem pemerintahan Negara Kesatuan Republik Indonesia.

Desa bukanlah bawahan kecamatan, karena kecamatan merupakan bagian dari perangkat daerah kabupaten/kota, dan desa bukan merupakan bagian dari perangkat daerah.Berbeda dengan Kelurahan, Desa memiliki hak mengatur wilayahnya lebih luas.Namun dalam perkembangannya, sebuah desa dapat dirubah statusnya menjadi kelurahan.Desa adalah suatu kesatuan masyarakat hukum yang mempunyai susunan asli berdasarkan hak asal usul yang bersifat istimewa.Landasan pemikiran dalam mengenai pemerintahan desa adalah keanekaragaman, partisipasi, otonomi asli, demokratisasi dan pemberdayaan masyarakat.Penyelenggaraan pemerintahan desa 
merupakan subsistem dari sistem penyelenggaraan pemerintahan, sehingga desa memiliki kewenangan untuk mengatur dan mengurus kepentingan masyarakatnya.

Kepala desa merupakan pimpinan penyelenggaraan pemerintahan desa berdasarkan kebijakan yang ditetapkan bersama Badan Permusyawaratan Desa ( BPD). Masa jabatan kepala desa adalah enam tahun dan dapat diperpanjang lagi untuk satu kali masa jabatan.Kepala desa memiliki wewenang menetapkan peraturan desa yang telah mendapatkan persetujuan bersama BPD. Kepala desa pada dasarnya bertanggung jawab pada rakyat desa yang dalam tata cara prosedur pertanggung jawabannya disampaikan kepada bupati atau walikota melalui camat. Kepada BPD, kepala desa wajib memberikan pelaporan pertanggung jawabannya dan kepada rakyat menyampaikan informasi pokok-pokok pertanggung jawabannya, namun tetap harus memberi peluang kepada masyarakat melalui BPD untuk menanyakan atau meminta keterangan lebih lanjut terhadap hal-hal yang bertalian dengan pertanggung jawaban tersebut. Kepala desa dipilih langsung melalui pemilihan kepala desa (pilkades) oleh penduduk desa tersebut. Kewenangan kepala desa sesuai Undang-Undang Nomor 06 Tahun 2014 tentang Desa:

a. memimpin penyelenggaraan Pemerintahan Desa;

b. mengangkat dan memberhentikan perangkat Desa;

c. memegang kekuasaan pengelolaan Keuangan dan Aset Desa;

d. menetapkan Peraturan Desa;

e. menetapkan Anggaran Pendapatan dan Belanja Desa;

f. membina kehidupan masyarakat Desa;

g. membina ketenteraman dan ketertiban masyarakat Desa;

h. membina dan meningkatkan perekonomian Desa serta mengintegrasikannya agar mencapai perekonomian skala produktif untuk sebesar-besarnya kemakmuran masyarakat Desa;

i. mengembangkan sumber pendapatan Desa;

j. mengusulkan dan menerima pelimpahan sebagian kekayaan negara guna meningkatkan kesejahteraan masyarakat Desa;

k. mengembangkan kehidupan sosial budaya masyarakat Desa;

1. memanfaatkan teknologi tepat guna;

m. mengoordinasikan Pembangunan Desa secara partisipatif; 
n. mewakili Desa di dalam dan di luar pengadilan atau menunjuk kuasa hukum untuk mewakilinya sesuai dengan ketentuan peraturan perundang-undangan; dan

o. melaksanakan wewenang lain yang sesuai dengan ketentuan peraturan perundang-undangan.

Kewajiban kepala desa sesuai Undang-Undang Nomor 06 Tahun 2014 :

a. memegang teguh dan mengamalkan Pancasila, melaksanakan Undang-Undang Dasar Negara Republik Indonesia Tahun 1945, serta mempertahankan dan memelihara keutuhan Negara Kesatuan Republik Indonesia, dan Bhinneka Tunggal Ika;

b. meningkatkan kesejahteraan masyarakat Desa;

c. memelihara ketenteraman dan ketertiban masyarakat Desa;

d. menaati dan menegakkan peraturan perundang-undangan;

e. melaksanakan kehidupan demokrasi dan berkeadilan gender;

f. melaksanakan prinsip tata Pemerintahan Desa yang akuntabel, transparan, profesional, efektif dan efisien, bersih, serta bebas dari kolusi, korupsi, dan nepotisme;

g. menjalin kerja sama dan koordinasi dengan seluruh pemangku kepentingan di Desa;

h. menyelenggarakan administrasi Pemerintahan Desa yang baik;

i. mengelola Keuangan dan Aset Desa;

j. melaksanakan urusan pemerintahan yang menjadi kewenangan Desa;

k. menyelesaikan perselisihan masyarakat di Desa;

1. mengembangkan perekonomian masyarakat Desa;

m. membina dan melestarikan nilai sosial budaya masyarakat Desa;

n. memberdayakan masyarakat dan lembaga kemasyarakatan di Desa;

o. mengembangkan potensi sumber daya alam dan melestarikan lingkungan hidup; dan

p. memberikan informasi kepada masyarakat Desa. 
Dari pengertian di atas dapat diketahui bahwa kepala desa mempunyai peranan dan juga kedudukan yang sangat penting dalam pemerintahan desa.Ia merupakan pemimpin terhadap jalannya tata urusan pemerintahan yang ada di desa. Seorang kepala desa merupakan penyelenggara dan sekaligus sebagai penanggung jawab atas jalannya roda pemerintahan dan pembangunan di dalam wilayahnya.Di samping menjalankan urusan pemerintahan dan pembangunan, kepala desa juga mempunyai kewajiban lain yaitu menyelenggarakan urusan dibidang kemasyarakatan membina ketentraman dan ketertiban masyarakat serta membina dan mengembangkan semangat gotong royong masyarakat.

Dengan berbagai kenyataan seperti di atas maka dapat dikatakan bahwa tugas dan kewajiban seorang kepala desa amatlah berat. Mengingat tugasnya yang berat tersebut maka dalam menjalankan tugas dan kewajibannya terutama dalam hal menjalankan serta meningkatkan pembangunan bagi masyarakatnya ia perlu dibantu oleh perangkat desa yang lain di samping perlu baginya untuk mengadakan kerjasama dan koordinasi dengan aparat pemerintah yang ada di atasnya maupun dengan aparat lain yang terkait.

Sebagai seorang kepala desa, sekaligus pemimpin dalam pemerintahan desa maka seorang kepala desa harus mempunyai jiwa pemimpin, mampu dan mau bekerja sama dengan para perangkat desa yang lainnya maupun dangan aparat pemerintah lain di atasnya dalam menjalankan tugas dan kewajibannya, mengingat fungsinya dalam pembangunan yaitu :

a. Sebagai stabilisator

b. Sebagai innovator

c. Sebagai pelopor

Pemerintah Desa menurut Undang-Undang Nomor 06 Tahun 2014 tentang Desa, adalah Kepala Desa atau yang disebut dengan nama lain dibantu perangkat Desa sebagai unsur penyelenggara Pemerintahan Desa.Perangkat desa sebagaimana dimaksud terdiri atassekretariat Desa, pelaksana kewilayahan; dan pelaksana teknis.

\section{Pembangunan Desa}

Dalam Undang-undang No. 6 Tahun 2014 Pasal 78 ayat (1), disebutkan bahwa Pembangunan Desa bertujuan meningkatkan kesejahteraan masyarakat Desa dan kualitas hidup manusia serta penanggulangan kemiskinan melalui pemenuhan 
kebutuhan dasar, pembangunan sarana dan prasarana Desa, pengembangan potensi ekonomi lokal, serta pemanfaatan sumber daya alam dan lingkungan secara berkelanjutan, kemudian ayat (2) disebutkan bahwa Pembangunan Desa meliputi tahap
a. perencanaan,
b. pelaksanaan, dan
c. pengawasan.

Sebagaimana ketentuan pasal 78 ayat (3) Undang Undang Nomor 6 Tahun 2014 disebutkan bahwa pembangunan Desa mengedepankan kebersamaan, kekeluargaan, dan kegotongroyongan guna mewujudkan pengarusutamaan perdamaian dan keadilan sosial.

Prioritas, program, kegiatan, dan kebutuhan Pembangunan Desa dirumuskan berdasarkan penilaian terhadap kebutuhan masyarakat Desa yang meliputi:

1. peningkatan kualitas dan akses terhadap pelayanan dasar;

2. pembangunan dan pemeliharaan infrastruktur dan lingkungan berdasarkan kemampuan teknis dan sumber daya lokal yang tersedia;

3. pengembangan ekonomi pertanian berskala produktif;

4. pengembangan dan pemanfaatan teknologi tepat guna untuk kemajuan ekonomi; dan

5. peningkatan kualitas ketertiban dan ketenteraman masyarakat Desa berdasarkan kebutuhan masyarakat Desa.

Pengertian pembangunan desa juga dapat dilihat dari berbagai segi yaitu: (1) Pembangunan desa sebagai suatu "Proses", yaitu merupakan suatu perubahan dari cara hidup tradisional masyarakat pedesaan menuju cara hidup yang lebih maju. Dalam pada ini pembangunan desa lebih di tekankan pada aspek perubahan yang terjadi dalam kehidupan masyarakat, baik yang menyangkut segi-segi sosial, ekonomi maupun psykologis; (2) Pembangunan desa sebagai suatu "Metode", yaitu mengusahakan agar masyarakat berkemampuan dalam membangun diri mereka sendiri sesuai dengan kemampuan dari sumber-sumber yang mereka miliki. Jadi pembangunan desa di sini lebih ditekan pada cara-cara untuk mencapai atau mewujudkan tujuan-tujuan pembangunan; (3) Pembangunan desa sebagai suatu “ Program”, yaitu untuk meningkatkan taraf hidup dan kesejahteraan masyarakat, lahir dan bathin. 
Pembangunan desa di sini lebih ditekankan kepada bidang kegiatan pemerintah dalam pelayanan terhadap masyarakat, seperti di bidang pendidikan, kesehatan, pertanian, industri, koperasi, keluaga berencana dan transmigrasi dan lain-lain; (4) Pembangunan desa sebagai suatu "Gerakan", yaitu yang tekanannya lebih diarahkan untuk menunjukkan masyarakat secara terkoordinir dan terarah sesuai dengan cita-cita nasional kita, yaitu terwujudnya "masyarakat Pancasila" yang kita inginkan bersama. Jadi penekanan pembangunan desa di sini adalah dalam kerangka ideologis yang mendasar yang mengarahkan proses, metoda dan program pembangunan desa.

Pembangunan desa pada khakekatnya merupakan kegiatan terencana mengandung tiga unsur pokok, yakni metode, proses dan tujuan.

a. Metode pembangunan desa yang baik harus melibatkan seluruh anggota masyarakat dan menyangkut kegiatan yang berkaitan langsung dengan kepentingan sosio-ekonomis mereka.

b. Sebagai proses, pembangunan desa merupakan proses transformasi budaya yang diawali dengan kehidupan tradisional yang mengandalkan kebiasaan-kebioasaan turun temurun untuk diubah menjadi masyarakat modern yang mendasarkan kemajuan hidup pada kesediaan menerima ilmu pengetahuan dan teknologi.

c. Sebagai tujuan, pembangunan desa bertujuan untuk memperbaiki taraf hidup, menciptakan kesempatan yang lebih baik bagi pengembangan mata pencaharian, serta mengusahakan terciptanya prasarana fisik dan pelayanan social yang sama dengan daerah perkotaan.

Tujuan pembangunan desa adalah sebagai berikut:

a. Menjangkau kelompok masyarakat yang masih hidup di bawah garis kemiskinan.

b. Menangani dan mengatasi secara cepat masalah-masalah yang mendesak, ketimpangan dan kesenjangan antara pedesaan dan perkotaan.

c. Mengatasi masalah lapangan kerja.

d. Melembagakan secara mendasar missi pemerintah pada seluruh masyarakat.

e. Menjaga kesinambungan pembangunan

\section{DESKRIPSI WILAYAH PENELITIAN}

Kecamatan Mekarsari merupakan salah satu Kecamatan di Kabupaten Barito Kuala yang terletak disebelah selatan dari pusat Pemerintahan Kabupaten Barito Kuala, 
mempunyai jumlah pendudukk 17.235 jiwa dengan luas wilayah $143,5 \mathrm{Km}^{2}$ dan merupakan daerah pasang surut yang mempunyai ketinggian satu meter dari permukaan laut.

Kecamatan Mekarsari berdiri sejak tahun 1986 pemekaran dari Kecamatan Tamban.Dengan berlakunya Peraturan Pemerintah No 43 Tahun 1986 tentang Pembentukan Kecamatan Aranio di daerah Kabupaten Banjar.Kecamatan Mekarsari dan Kecamatan Barambai di Kabupaten daerah Tingkat II Barito Kuala dll.Adapun letak wilayah Kecamatan Mekarsari, sebelah Utara berbatasan dengan Kecamatan Anjir Muara, Selatan berbatasan dengan Kecamatan Tabunganen, Timur berbatasan dengan Kecamatan Tamban, dan Sebelah Barat berbatasan dengan Kecamatan Kapuas Kuala. Secara administratif Kecamatan Mekarsari terdiri dari 9 (Sembilan) Desa yaitu sebagai berikut:

1. Desa Tamban Raya

2. Desa Tamban Raya Baru

3. Desa Karang Mekar

4. Desa Mekar Sari

5. Desa Indah Sari

6. Desa Tinggiran Darat

7. Desa jelapat II

8. Desa Tinggiran Baru; dan

9. Desa Tinggiran Tengah

Kecamatan Mekarsari terletak digaris katulistiwa, termasuk daerah hujan tipe B yaitu iklim yang mempunyai 1-2 bulan kemarau dalam satu tahun. Temperatur rata-rata 26-27 $7^{0}$ Derejat Celcius dan suhu minimum 26,50 ${ }^{\circ}$ Derajat celcuis.Sedangkan angka rata-rata hujan setiap tahunnya aalah 2,665mm dengan107 hari hujan. Oleh karena itu mata pencaharian penduduk Kecamatan Mekarsari sebanyak $80 \%$ adalah sebagai petani sawah dan kebun, sebanyak 5\% pedagang, sebanyak 10\% karyawan industri aatu poegawai, dan lain-lain sebanyak 5\%.Potensi wilayah adalah pertanian dan perkebunan, sebagian besar perkebunan nanas yang dibudidayakandan yang paling menonjol.

\section{METODOLOGI PENELITIAN}

\section{A. Jenis Penelitian}


Jenis penelitian ini adalah jenis deskriptif yaitu ditujukan untuk mengumpulkan informasi faktual secara terperinci dan menentukan apa yang harus dilakukan oleh orang atau lembaga tertentu dalam menghadapi suatu permasalahan kemudian menerapkan keputusan tersebut untuk menghadapi masalah yang sama pada waktu yang akandatang atau pada tempat yang berbeda.

\section{B. Informan}

Informandalam penelitian ini adalah seluruh Kepala Desa yang ada di Kecamatan Mekarsari yang berjumlah 9 orang

\section{Jenis dan Sumber Data}

Dalam penelitian ini jenis data yang dikumpulkan adalah data primer dan data sekunder.

a. Data primermerupakan data peneliti yang diperoleh secara langsung dari sumber asli (tidak melalui media perantara).

b. Data sekunder adalah data yang diperoleh peneliti secara tidaklangsung melalui media perantara (diperoleh dan dicatat oleh pihak lain).Data sekunder umumnya berupa bukti, catatan atau laporan historis yangtelah tersusun dalam arsip (data dokumenter) yang dipublikasikan dan yangtidak dipublikasikan.

\section{Teknik Pengumpulan Data}

Teknik pengumpulan data dalam penelitian ini adalah sebagai berikut:

1. Observasi, melihat keadaan yang sebenarnya yang terlihat dilapangan.

2. Dokumentasi merupakan sumber informasi berupa bahan tertulis

3. Wawancara secara berstruktur yang akan ditanyakan kepada Kepala Desa yang ada di Kecamatan Mekarsari yang berjumlah 9 orang.

\section{E. Teknik Analisa Data}

Teknik analisa data yang digunakan dalam penelitian ini adalah analisa kualitatif, yaitu analisa data berupa penjelasan-penjelasan.Dari data yang dikumpulkan diuraikan dan disesuaikan antara teori dengan praktek yang benar dan diterjemahkan kemudian ditarik kesimpulan.Dengan melalui teknik triangulasi dan sumber data.

\section{HASIL DAN PEMBAHASAN}




\section{A. Peran Kepala Desa Dalam Pembangunan Desa di Kecamatan Merkarsari Kabupaten Barito Kuala}

Kepala Desa di Kecamatan Mekarsari mempunyai peranan dan kedudukan yang sangat penting dalam pemerintahan desa.Kepala Desa merupakan pemimpin terhadap jalannya tata urusan pemerintahan yang ada di desa merupakan penyelenggara dan sekaligus sebagai penanggung jawab atas jalannya roda pemerintahan dan pembangunan di dalam wilayahnya.Di samping menjalankan urusan pemerintahan dan pembangunan, kepala desa juga mempunyai kewajiban lain yaitu menyelenggarakan urusan dibidang kemasyarakatan membina ketentraman dan ketertiban masyarakat serta membina dan mengembangkan semangat gotong royong masyarakat.

Ada banyak peran sebagai Kepala Desa, dalam penelitian ini ada tiga kelompok penting sebagai Kepala Desa dalam pembangunan di Kecamatan Mekarsari khususnya yaitu sebagai pelopor, sebagai innovator dan sebagai stabilisator. Berdasarkan hasil penelitian dengan melakukan wawancara kepada beberapa Kepala Desa yang ada di Kecamatan Mekarsari tentang peran Kepala Desa dalam pembangunan adalah sebagai berikut:

1. Kepala Desa Sebagai Pelopor

Berdasarkan hasil wawancara dengan beberapa Kepala Desa tersebut diatas, dapat diketahui peran Kepala Desa sebagai pelopor dalam pembangunan Desa di Kecamatan Mekarsari Kabupaten Barito Kuala adalah dengan menjadi sebagai pemimpin rapat, mengusulkan pembangunan dan mengajukan peraturan Desa, mengkoordinasikan pembangunan desa secara partisipatif, mengajukan rancangan peraturan desa mengenai APB Desa dan ditetapkan bersama BPDserta melaksanakan wewenang sesuai undang-undang.

2. Kepala Desa Sebagai Inovator

Berdasarkan hasil wawancara dengan beberapa Kepala Desa tersebut peran Kepala Desa sebagai inovator yaitu dengan mengembangkan potensi SDA dan melestarikan lingkungan hidup, menyelenggarakan dan melaksanakan administrasi pemerintahan desa yang baik dan mengkoordinasikan pembangunan desa.

3. Kepala Desa Sebagai Stabilisator

Berdasarkan hasil wawancara dengan beberapa Kepala Desa terkait peran Kepala Desa sebagai stabilisator dalam pembangunan Desa yaitu dengan 
melakukan mewakili desanya di dalam dan di luar pengadilan dan dapat menunjuk kuasa hukum untuk mewakilinya sesuai dengan peraturan perundang-undangan, membina ketertiban masyarakat, menyelesaikan dan mendamaikan perselisihan atau salah paham antar warga dan Desa, membina, mengayomi dan melestarikan nilainilai sosial budaya dan adat-istiadat.

\section{B. Kendala Kepala Desa Dalam Pembangunan Desa di Kecamatan Merkarsari Kabupaten Barito Kuala}

Berdasarkan hasil wawancara dengan beberapa Kepala Desa tersebut tentang kendala Kepala Desa dalam melaksanakan pembangunan Desa di Kecamatan Mekarsar Kabupaten Barito Kuala dapat disimpulkan sebagai berikut:

1. Masih rendahnya kualitas Sumber Daya Manusia atau pendidikan aparat dan masyarakat yang melaksanakan proses pembangunan Desa di Kecamatan Mekarsari.

2. Terbatasnya anggaran untuk pembangunan Desa di Kecamatan Mekarsari.

3. Rendahnya tunjangan untuk Kepala Desa sehingga tingkat kesejahteraan kepala desa sangat rendah.

4. Kurangnya pengawasan dan pembinaan kepada Kepala Desa dari Pemerintah Daerah.

Dengan demikian dapat diketahui kendala Kepala Desa dalam melaksakan pembangunan di Kecamatan Mekarsari Kabupaten Barito Kuala yang selama ini menghambat proses pembangunan di Kecamatan Mekarsari yang harus segera diatasi agar pembangunan berjalan lancar.

C. Solusi yang dilakukan Kepala Desa Dalam Pembangunan Desa di Kecamatan Merkarsari Kabupaten Barito Kuala

Berdasarkan hasil wawancara dengan beberapa Kepala Desa tersebut tentang solusi Kepala Desa dalam melaksanakan pembangunan Desa di Kecamatan Mekarsar Kabupaten Barito Kuala dapat disimpulkan sebagai berikut:

1. Meningkatkan kualitas Sumber Daya Manusia dan pendidikan aparat serta masyarakat yang melaksanakan proses pembangunan Desa di Kecamatan Mekarsari.

2. Mengusulkan tambahan anggaran untuk pembangunan Desa di Kecamatan Mekarsari. 
3. Meningkatkan tunjangan untuk Kepala Desa sehingga tingkat kesejahteraan kepala desa menjadi lebih baik.

4. Meningkatkan pengawasan dan pembinaan kepada Kepala Desa dari Pemerintah Daerah, sehingga pelaksanaan pembangunan berjalan lancar.

Dengan demikain dapat diketahui solusi yang digunakan untuk mengatasi kendala dalam pelaksanaan pembangunan di Kecamatan Mekarsari Kabupaten Barito Kuala agar pembangunan berjalan lancar dan sesuai dengan perencanaan pembangunan yang telah ditentukan.

\section{PENUTUP}

\section{A. Kesimpulan}

Berdasarkan hasil penelitian dan pembahasan tersebut diatas, maka penelitian ini dapat disimpulkan sebagai berikut:

1. Peran Kepala Desa dalam pembangunan Desa di Kecamatan Mekarsari sebagai polopor, innovator dan stabilisator dengan melakukan berbagai perencanaan, usulan dan tindakan dalam mencapai tujuan pembangunan Desa yang lebih baik. Hasil pembangunan terlihat dengan adanya beberapa pembangunan seperti Jalan, Jembatan dan pembangunan sarana lainnya.

2. Kendala Kepala Desa dalam melaksanakan pembangunan Desa di Kecamatan Mekarsar Kabupaten Barito antara lain:

a. Masih rendahnya kualitas Sumber Daya Manusia atau pendidikan aparat dan masyarakat yang melaksanakan proses pembangunan Desa di Kecamatan Mekarsari.

b. Terbatasnya anggaran untuk pembangunan Desa di Kecamatan Mekarsari.

c. Rendahnya tunjangan untuk Kepala Desa sehingga tingkat kesejahteraan kepala desa sangat rendah.

d. Kurangnya pengawasan dan pembinaan kepada Kepala Desa dari Pemerintah Daerah.

3. Solusi Kepala Desa dalam melaksanakan pembangunan Desa di Kecamatan Mekarsari Kabupaten Barito Kuala antara lain: 
a. Meningkatkan kualitas Sumber Daya Manusia dan pendidikan aparat serta masyarakat yang melaksanakan proses pembangunan Desa di Kecamatan Mekarsari.

b. Mengusulkan tambahan anggaran untuk pembangunan Desa di Kecamatan Mekarsari.

c. Meningkatkan tunjangan untuk Kepala Desa sehingga tingkat kesejahteraan kepala desa menjadi lebih baik.

d. Meningkatkan pengawasan dan pembinaan kepada Kepala Desa dari Pemerintah Daerah, sehingga pelaksanaan pembangunan berjalan lancar.

\section{DAFTAR PUSTAKA}

Ade Hermawan, dkk, 2017. Pedoman Penulisan Proposal dan Skripsi Progran Sarjana (S1), STIA Bina Banua Banjarmasin.

Darsono, 2005.Pedoman Praktis Memahami laporan Keuangan, Andi, Yogyakarta

Edi Suharto, 2010. Analisis Kebijakan Publik. CV Alfabeta. Bandung.

Hijrah Khaerana, 2012. Peranan Kepala Desa Dalam Pemberdayaan Masyarakat di Desa Tinggimae Kecamatan Barombong Kabupaten Goa.

Surat Edaran Bersama Menteri Negara Perencanaan Pembangunan Nasional dan Menteri Dalam Negeri (Mendagri) Tahun 2006 Tentang Petunjuk Teknis Penyelenggaraan Musrenbang.

Undang-Undang Republik Indonesia Nomor 6 Tahun 2014 Tentang Desa. 